\title{
SISTEM HIRARKI KELEMBAGAAN BADAN PENGELOLA ZAKAT DI INDONESIA (Tinjauan Terhadap Pelaksanaan Undang-Undang Nomor 23 Tahun 2011)*
}

\author{
Mufidah \\ Pusat Studi Konstitusi dan Legislasi Nasional (Posko-Legnas) \\ Jl. Ir. H. Juanda No. 95 Ciputat Tangsel \\ Email: vdamoe@gmail.com \\ DOI: $10.15408 /$ jch.v4i2.3673
}

\begin{abstract}
Government support for the existence and role of zakat management organization indicated by the issuance of legislation on the management of zakat that Act No. 38 of 1999 and the decision of the Minister of Religion No. 581 of 1999 on the implementation of Act No. 38 of 1999 which was amended by Act No. 23 of 2011 concerning the management of zakat.Many factors of causing non-optimal zakat as legislation, mostly related to the system and institutional factors. In this case, should the government as well as amil zakat organization has a strategic role to establish an institutional system of zakat and charity empowerment and support the establishment of the implementation of the charity as a binding regulation. This can occur if the control system of zakat management organization operating effectively, as well as the existence of legislation on the management of zakat either No. 38 of 1999 and No. 23 of 2011. In other words, the optimization of the implementation of zakat is affected by the system and the effective management of zakat management in addition to firmness of government in enforcing the implementation of zakat either written in the legislation and are implementable in order to achieve good governance zakat (alms good governance).
\end{abstract}

Keywords: Management Systems, Zakat, Law No. 23 of 2011

Abstrak: Dukungan pemerintah terhadap keberadaan dan peran organisasi pengelola zakat ditunjukkan dengan dikeluarkannya peraturan perundang-undangan tentang pengelolaan zakat yaitu Undang-undang Nomor 38 Tahun 1999 dan Keputusan Menteri Agama Nomor 581 Tahun 1999 tentang Pelaksanaan Undang-Undang Nomor 38 Tahun 1999 yang kemudian diperbaharui dengan Undang-undang Nomor 23 Tahun 2011 tentang Pengelolaan Zakat. Beberapa faktor penyebab belum optimalnya formalisasi zakat dengan peraturan perundang-undangan adalah terkait dengan faktor sistem dan kelembagaan. Semestinya, baik pemerintah maupun lembaga pengelola zakat sebagai amil memiliki peran yang sangat strategis dalam membangun sistem kelembagaan zakat, pemberdayaan zakat serta mendukung tegaknya pelaksanaan kebijakan tentang zakat. $\mathrm{Hal}$ ini dapat terwujud jika sistem pengendalian organisasi pengelolaan zakat berjalan dengan efektif. Optimalisasi pelaksanaan zakat selain dipengaruhi oleh sistem dan manajemen pengelolaan zakat yang efektif juga diperlukan ketegasan pemerintah dalam implementasi kebijakan tentang zakat demi terwujudnya tata kelola zakat yang baik.

Kata Kunci: Sistem Pengelolaan, Zakat, Undang-undang No. 23 Tahun 2011

\footnotetext{
* Naskah diterima: 20 Mei 2016, direvisi: 25 Juli 2016, disetujui untuk terbit: 21 September
} 2016. 


\section{Pendahuluan}

Keberadaan Undang-Undang Nomor 38 Tahun 1999 yang disahkan untuk pertama kalinya dan diamandemen dengan Undang-Undang Nomor 23 Tahun 2011 tentang Pengelolaan Zakat telah menggeser paradigma pelaksanaan zakat. Indikator yang dapat dilihat sebagai salah satu kelebihan undang-undang tersebut adalah adanya suatu badan atau lembaga sebagai wadah penerima, penyalur serta pendistribusi zakat yang tidak hanya dikelola masyarakat tetapi juga badan pengelola di bawah naungan pemerintah. Undang-Undang tentang Pengelolaan Zakat sekaligus juga memberi makna bahwa zakat di Indonesia bukan sekedar pelaksanaan ubudiyah yang sifatnya hanya ritual keagamaan, lebih dari itu pelaksanaan zakat merupakan bagian dari produk hukum positif yang seharusnya dapat ditertibkan melalui perangkat negara.

Peraturan perundang-undangan tentang pengelolaan zakat juga mengubah paradigma tata kelola zakat dalam bentuk kepanitiaan menjadi tata kelola lembaga. Zakat yang semula dikelola dengan sumber daya manusia yang apa adanya, kini menggunakan kualifikasi standar bisnis dalam sebuah perusahaan. Demikian halnya dalam hal manajemen pendistribusian zakat, juga mengalami perkembangan. Pendistribusian zakat yang semula hanya bersifat penyaluran saja, kini diorganisir dengan bentuk pengembangan sehingga zakat dapat dinikmati tidak hanya pada momen Ramadhan tetapi juga dapat dirasakan manfaatnya sepanjang bulan dan sepanjang tahun.

Selain beberapa kelebihan disahkannya Undang-Undang tentang Pengelolaan Zakat sebagaimana diuraikan di atas juga terdapat adanya beberapa faktor yang juga dianggap sebagai kelemahan dari peraturan tersebut sehingga pelaksanaan kebijakan tentang zakat belum dapat dilaksanakan dengan maksimal. Undang-undang tersebut belum sepenuhnya menertibkan tata kelola zakat sesungguhnya, misalnya tidak diberlakukannya efek jera terhadap muzakki yang lalai membayar zakat atau bentuk punishment terhadap keterlambatan membayar zakat. ${ }^{1}$ Hal lain yang semestinya juga menjadi penting dalam Peraturan perundang-undangan Zakat adalah mekanisme sistem pengendali organisasi.

Pelaksanaan zakat sebagaimana menurut undang-undang adalah sebagai penjamin amanah agama semata. Hal tersebut sebagaimana termaktub dalam Pasal 8 Undang-Undang Nomor 23 Tahun 2011 tentang Pengelolaan Zakat

\footnotetext{
1"Kelemahan Undang-Undang Zakat” lihat http://bwi.or.id/index.php/ar/berita-mainmenu109/313-uu-zakat-miliki-tiga-kelemahan, (Rabu, 17 September 2014).
} 
dimana unsur pertimbangan dan unsur pengawasan terdiri atas ulama, kaum cendekiawan, masyarakat, dan pemerintah serta adanya sanksi hukum terhadap pengelolaan zakat yang melakukan penyimpangan. ${ }^{2}$ Hal ini diyakini sebagai salah satu kelemahan sistem managemen yang hanya diatur secara sederhana. Terlebih pada pasal sebelumnya, yakni Pasal 7 ayat (3) yang mana pelaksanaan pengelolaan zakat hanya dilaporkan dengan mekanisme singkat secara tertulis kepada Presiden melalui Menteri dan DPR RI tanpa ada lembaga yang mengaudit terlebih dahulu.

Dewan Pleno Forum Zakat (FOZ) juga menilai bahwa terdapat kelemahan dalam undang-undang tersebut seperti ketidakjelasan peran regulator, operator, koordinator dan pengawas dalam penataan kelembagaan zakat yang mana sampai saat ini menambah dualisme manajemen antara LAZ (Lembaga Amil Zakat) yang merupakan milik masyarakat dan BAZ (Badan Amil Zakat) yang merupakan milik pemerintah. ${ }^{3}$

Undang-undang tentang pengelolaan zakat sebagaimana diperkuat dengan Peraturan Pemerintah Nomor 14 Tahun 2014 mendudukan BAZNAS sebagai badan resmi yang ditunjuk pemerintah untuk mengelola zakat secara signifikan. Pada saat bersamaan keberadaan BAZNAS juga akan melemahkan posisi Lembaga Amil Zakat (LAZ) yang selama ini justru menjadi pelopor dalam manajemen zakat yang diinisiasi masyarakat. ${ }^{4}$ Hal ini tentu akan memecah struktur pengelola zakat, yang semestinya satu atap. Padahal tujuan lahirnya peraturan perundang-undangan zakat sudah hampir dipastikan untuk menjaga ketertiban, kesadaran serta pendayagunaan zakat yang maksimal, bukan menghambat pelaksanaannya.

Selazimnya sebuah organisasi, dengan disahkannya undang-undang tentang pengelolaan zakat yang melibatkan pemerintah, semestinya terbangun sebuah sistem yang berjenjang. Demikian pula pemetaan wilayah, wewenang, tugas dan fungsi pengelola zakat baik bentukan masyarakat (LAZ) maupun pemerintah (BAZ) juga terbaca jelas dalam peraturan perundang-undangan tersebut sehingga manajemen pengelolaan dapat dilakukan secara terpadu agar tercipta keselarasan antara BAZ dan LAZ.

${ }^{2}$ Gustian Djuanda dkk, Pengelolaan Zakat Pengurang Pajak Penghasilan, (Jakarta: PT. Raja Grafindo Persada, 2006), h. 4.

3"Kelemahan Undang-Undang Zakat" diunduh dari http://bwi.or.id/index.php/ar/beritamainmenu-109/313-uu-zakat-miliki-tiga-kelemahan, (Rabu, 17 September 2014).

4 “Tikungan Tajam Amil Zakat" diunduh dari www. kliping.kemenag.go.id/download.php\% (Senin 14 April 2014), h.102-103. 


\section{Mufidah}

\section{Sekilas tentang Pengaturan Zakat di Indonesia}

Sejarah perkembangan Islam di Indonesia mencatat bahwa zakat mempunyai peranan penting dalam pembangunan bangsa. Banyak tempattempat kegiatan keagamaan Islam seperti masjid dan tempat ibadah, madrasah/sekolah, panti asuhan, pondok pesantren, rumah sakit Islam dan lain-lain dibangun dengan dana zakat. ${ }^{5}$ Banyak sekali potensi yang terkandung dalam zakat, terutama jika dikelola dengan baik. Jika merujuk data populasi kemiskinan di Indonesia tahun 2009 tercatat sekitar 32,53 juta jiwa atau 14,15\%, dan sebanyak $63,68 \%$ berada di daerah pedesaan, ${ }^{6}$ hal ini bertentangan dengan status Indonesia sebagai negara muslim terbesar di dunia.

Sejak awal kemerdekaan Indonesia, pemerintah sejatinya telah memiliki perhatian terhadap zakat. Sejarah mencatat bahwa implementasi zakat di awali dengan Ssurat Edaran Nomor A/VII/17367 pada tanggal 8 Desember 1951 tentang pelaksanaan Zakat Fitrah. ${ }^{7}$ Isi surat edaran tersebut menegaskan bahwa peran pemerintah pada saat itu sebagai motivator saja sehingga penulis meyakini bahwa pada saat itu pemerintah tidak terlibat banyak dalam hal penghimpunan, pengelolaan maupun pendistribusiannya. Dalam konteks pelaksanaa zakat, pemerintah hanya melakukan pengawasan agar pelaksanaan dapat berjalan sesuai syariat Islam. Sejarah lain juga mencatat bahwa pada masa di berlakukannya UUDS tahun 1950, Menteri Keuangan Republik Indonesia, M. Jusuf Wibisono mengemukakan gagasannya dalam sebuah makalah yang dimuat pada Majalah Hikmah Jakarta (1950) untuk memasukkan zakat sebagai salah satu komponen sistem perekonomian Indonesia. Gagasan tersebut pada saat itu selaras dengan sebagian anggota parlemen yang menginginkan agar zakat juga diatur sebagai peraturan perundang-undangan dan diurus langsung oleh pemerintah atau negara.

Pada era reformasi tahun 1998, lahir Undang-Undang Nomor 38 Tahun 1999 tentang Pengelolaan Zakat yang ditandatangani pada 23 September 1999 oleh Presiden RI, B.J. Habibie. Pada tahun yang sama Menteri Agama RI juga membuat Surat Keputusan Nomor 581 Tahun 1999 sebagai peraturan pelaksana dari Undang-Undang Nomor 38 Tahun 1999 tentang Pengelolaan Zakat. Beberapa tahun kemudian Menteri Agama RI mengeluarkan Keputusan Nomor

5Tulus, Pemberdayaan Lembaga Pengelolaan Zakat dan Kaitannya dengan Pajak (Jakarta: Forum Zakat, 2003), h. 91.

'Suradi dan Mujiyadi, Pemberdayaan Masyarakat Miskin (Studi Evaluasi Penanggulangan Kemiskinan di Lima Provinsi, (Jakarta: P3KS Press, 2009), h. 5.

${ }^{7}$ Arskal Salim, Pengelolaan Zakat dalam Politik Orde Baru dalam Problematika Zakat Kontemporer; Artikulasi Proses Sosial Politik Budaya, (Jakarta: Forum Zakat (FOZ), 2003), h. 147-148. 
373 Tahun 2003 sebagai pengganti Keputusan Nomor 581 Tahun 1999. Di tahun 2000, Dirjen Bimas Islam dan Urusan Haji membuat Keputusan Nomor D/291/2000 tentang Pedoman Teknis Pengelolaan Zakat. Dengan disahkannya Undang-Undang Nomor 38 Tahun 1999 tentang Pengelolaan Zakat tersebut, Indonesia memasuki tahap institusionalisasi pengelolaan zakat dalam wilayah formal kenegaraan, kendati masih sangat terbatas. Lembaga-lembaga pengelola zakat mulai berkembang dengan menagemen yang lebih baik dan modern, baik lembaga zakat yang dikelola oleh pemerintah seperti BAZNAS, BAZ maupun LAZ, lembaga zakat yang dikelola masyarakat. ${ }^{8}$

\section{Zakat dalam Kajian Yuridis; Ditinjau dari Falsafah Pancasila, UUD NRI Tahun 1945 dan Undang-undang}

Zakat merupakan instrumen yang sempurna untuk menterjemahkan prinsip Islam tentang persaudaraan dan rasa kemanusiaan ke dalam kehidupan yang nyata. Allah Swt dengan sangat jelas menghendaki agar zakat ditujukan sebagai sebuah bentuk kontribusi nyata terhadap rasa persaudaraan untuk meningkatkan kemajuan dan kesejahterakan antar sesama. Adanya rasa persaudaraan yang kuat memungkinan suatu negara akan menjadi kokoh. Kebersamaan dan persaudaraan inilah yang mengantar kewajiban kepada seseorang untuk menyisihkan sebagian harta benda dalam bentuk zakat, sadaqah atau infaq. ${ }^{9}$ Sudut pandang tersebut pula yang mungkin dijadikan pedoman ketika founding father membahas tentang cita-cita luhur bangsa Indonesia sebagaimana termaktup dalam Sila ke-3 Pancasila "Persatuan Bangsa Indonesia" yang diikuti dengan Sila ke-5 "Keadilan Sosial Bagi Seluruh Rakyat Indonesia"

Undang-Undang Dasar Negara Rerpublik Indonesia Tahun 1945 telah mengamanatkan tujuan nasional yang salah satunya adalah memajukan kesejahteraan umum. ${ }^{10}$ Dengan demikian, setiap warga negara mempunyai hak untuk mendapatkan penghidupan yang layak secara merata, baik secara materil maupun spirituil. Hal tersebut juga diakui sebagai salah satu hak asasi manusia yang dinyatakan dalam Declaration of Human Right sebagai berikut:

${ }^{8}$ Fakhruddin, Figh dan Manajemen Zakat di Indonesia, (Malang: UIN-Malang Press, 2008), h. 245-246.

9Ismail Muhammad Syah dkk, Filsafat Hukum Islam, (PT BumiAksara, Jakarta, 1999, Cet. III, h.190.

${ }^{10}$ Direktorat Jenderal Bimbingan Masyarakat Islam dan Penyelenggaran Haji Depag RI, Manajemen Pengelolaan Zakat, (Jakarta: Dirjen Bimas Islam dan Penyelenggaran Haji Depag RI 2004), h.1 
Setiap orang berhak atas tingkat hidup yang menjamin kesehatan dan keadaan baik dirinya sendiri dan keluarganya, termasuk soal makanan, pakaian, perumahan dan perawatan kesehatannya, serta usaha-usaha sosial yang diperlukan, berhak atas jaminan diwaktu mengalami pengganguran, janda, lanjut usia atau mengalami kekurangan nafkah karena keadaan diluar kekuasaanya. ${ }^{11}$

Pelaksanaan zakat satu sisi merupakan kewajiban agama namun di sisi lain pada dasarnya juga merupakan bentuk konkrit dari pengamalan Pancasila yaitu sila ke satu "Ketuhanan Yang Maha Esa" dan sekaligus merupakan pengamalan Konstitusi UUD NRI Tahun 1945 sebagaimana Pasal 29 Ayat 1 yang berbunyi "Negara berdasar atas ketuhanan Yang Maha Esa". ${ }^{12}$ Hal ini dapat diartikan bahwa ideologi yang dianut negara Indonesia adalah Ketuhanan Yang Maha Esa dan dapat dimaknai bahwa segala kegiatan di negara Indonesia harus berdasarkan pada prinsip Ketuhanan Yang Maha Esa. Dalam pembukaan (Preambule) Undang-Undang Dasar Negara Republik Indonesia Tahun 1945 juga disebutkan:

“..Pemerintah Negara Indonesia yang melindungi segenap bangsa Indonesia dan seluruh tumpah darah Indonesia dan untuk memajukan kesejahteraan umum, mencerdaskan kehidupan bangsa, dan ikut melaksanakan ketertiban dunia yang berdasarkan kemerdekaan, perdamaian abadi dan keadilan sosial..."

Prinsip ketuhanan yang ditanamkan dalam Pancasila maupun UUD NRI 1945 merupakan perwujudan dari pengakuan keagamaan. Hal ini merupakan pondasi atas disahkannya zakat sebagai perintah agama yang kini juga menjadi bagian daripada kebijakan negara (undang-undang) yang berlaku umum dan harus dipatuhi seluruh masyarakat Indonesia, khususnya yang beragama Islam. Landasan yuridis zakat juga merujuk pada ketentuan konstitusi yang menyebutkan bahwa fakir miskin dan anak-anak terlantar dipelihara oleh negara sebagaimana ditegaskan pada Pasal 34 Ayat 1 UUD 1945 bahwa negara memiliki kewajiban untuk memelihara fakir miskin dan anakanak terlantar serta melakukan pemberdayaan terhadap mereka.

Zakat mempunyai sifat ekonomis sekaligus religius dan berkaitan erat dengan kebijaksanaan pemerataan untuk mencapai keadilan sosial. ${ }^{13}$ Seseorang yang telah memenuhi syarat wajib zakat, dituntut untuk menunaikannya. Perintah tersebut bukan semata-mata atas dasar kemurahan hatinya, akan

${ }^{11}$ Lihat Declaration of Human Right, Pasal 25 ayat (1)

${ }^{12}$ Undang-Undang Dasar Negara Republik Indonesia 1945 Pasal 29 Ayat 1

${ }^{13}$ Abdullah Kelib, "Falsafah Zakat dalam Hukum Islam" artikel dalam Majalah Hukum, Vol I Tahun 2007, h. 97. 
tetapi perlu adanya tekanan pemerintah sebagai bentuk kewajiban pelaksanaannya. ${ }^{14}$ Formalisasi zakat melalui undang-undang merupakan salah satu upaya menjabarkan adanya prinsip ketuhanan dan keadilan sosial yang terdapat dalam Pancasila. Melalui zakat, prinsip ketuhanan dapat terlihat, demikian pula prinsip keadilan sosial juga terwujud dengan penempatan pemerataan dan solidaritas sosial sebagai prinsip penting karena zakat merupakan salah satu ajaran agama (khususnya Islam).

Landasan filosofi bagi formalisasi zakat melalui undang-undang adalah prinsip-prinsip yang terdapat dalam Pancasila terutama sila pertama, "Ketuhanan yang Maha Esa" dan sila kelima, "Keadilan sosial bagi seluruh rakyat Indonesia". Kedua sila tersebut menyiratkan pengertian bahwa bangsa Indonesia adalah bangsa yang berketuhanan yang berkeadilan. Melalui keadilan, bangsa Indonesia menempatkan pemerataan dan solidaritas sosial sebagai prinsip yang penting sehingga terdapat kehendak untuk berbagi demi kemaslahatan bersama, yang mana secara sosiologis juga menjadi kebutuhan mendesak akan lahirnya peraturan perundang-undangan yang dapat menciptakan tatakelola yang baik dalam pengelolaan zakat, infaq dan shadaqoh. ${ }^{15}$

\section{Bentuk dan Peranan Lembaga Keuangan, Sistem Pengawasan Lembaga Keuangan serta Kedudukan Otoritas Jasa Keuangan dalam Sistem Keuangan di Indonesia}

Lembaga keuangan merupakan bagian dari sistem keuangan dalam perekonomian modern yang melayani masyarakat pemakai jasa keuangan. Sistem keuangan pada dasarnya merupakan suatu jaringan pasar keuangan (financial market), institusi sektor usaha, rumah tangga dan lembaga pemerintah yang merupakan peserta dan juga sekaligus memiliki wewenang dalam mengatur operasi sistem keuangn tersebut. Definisi umum yang dimaksud dengan lembaga keuangan menurut undang-undang adalah semua badan yang melalui kegiatan-kegiatannya di bidang keuangan menaruh uang dari dan menyalurkannya ke dalam masyarakat. ${ }^{16} \mathrm{Hal}$ ini artinya bahwa kegiatan yang dilakukan oleh lembaga keuangan selalu berkaitan dengan bidang keuangan.

\footnotetext{
${ }^{14}$ Quraish Shihab, Membumikan Al Quran, (Bandung: Mizan, 1999), Cet. XIX, h. 323.

${ }^{15}$ Kementrian Agama RI, Standarisasi Amil Zakat di Indonesia (Jakarta: Direktorat Jenderal Bimbingan Masyarakat Islam, Direktorat Pemberdayaan Zakat, 2013), h. 34

${ }^{16}$ Lihat Pasal 1 Undang-Undang Nomor 14 Tahun 1967 tentang Pokok-Pokok Perbankan
} 
Terdapat Surat Keputusan Menteri Keuangan RI Nomor 792 Tahun 1990 yang menyatakan bahwa lembaga keuangan adalah semua badan usaha yang kegiatannya di bidang keuangan melakukan penghimpunan dana, penyaluran dana kepada masyarakat terutama dalam membiayai investasi pembangunan. ${ }^{17}$ Lembaga keuangan bank atau non bank merupakan lembaga keuangan yang memberikan jasa di bidang sirkulasi keuangan, seperti menerima, mengelola, menyalurkan dalam berbagai bentuk kegiatan sepeti pinjaman (kredit) atau menyalurkan dalam bentuk memberdayakan keuangan dalam bentuk dana produktif. ${ }^{18}$

Lembaga keuangan dibagi menjadi dua, yaitu:

1. Lembaga keuangan Bank, yaitu badan usaha yang menghimpun dana dari masyarakat dalam bentuk simpanan dan menyalurkan kepada masyarakat dalam bentuk kredit dan atau bentuk-bentuk lainnya dalam rangka meningkatkan taraf hidup rakyat banyak.

2. Lembaga keuangan Non Bank

Menurut Surat Keputusan Menteri keuangan RI Nomor KEP38/MK/IV/1972, lembaga keuangan bukan bank adalah semua lembaga atau badan yang melakukan kegiatan dalam bidang keuangan yang secara langsung maupun tidak langsung menghimpun dana dengan cara mengeluarkan surat-surat berharga kemudian menyalurkan kepada masyarakat terutama untuk membiayai perusahaanperusahaan.

Dilihat dari sifat operasinya, suatu lembaga atau organisasi dapat dibagi menjadi dua macam, Pertama, lembaga yang berorientasi untuk mendapatkan keuntungan (profit institution). Kedua, lembaga yang dalam menjalankan aktivitasnya tidak berorientasi mengumpulkan keuntungan (nonfor-profit institution) yang dalam bahasa lain sering disebut organisasi nirlaba. Kelangsungan sebuah organisasi nirlaba sangat bergantung dari berbagai sumbangan yang diberikan oleh pihak-pihak yang percaya kepada organisasi tersebut. Secara umum organisasi nirlaba adalah institusi yang yang dalam menjalankan operasinya tidak berorientasi mencari laba. Namun demikian, bukan berarti organisasi nirlaba tidak boleh menerima atau menghasilkan keuntungan. Keuntungan tersebut dipergunakan untuk menutupi biaya

\footnotetext{
17 Lihat Surat Keputusan Menteri Nomor 792 Tahun 1990

${ }^{18}$ Aris B. Setyawan, Ekonomi Moneter (Pokok-pokok Bahan Perkuliahan), h. 3.
} 
operasional atau disalurkan untuk kegiatan utamanya. ${ }^{19}$ Terdapat beberapa karakteristik yang melekat pada organisasi nirlaba antara lain:

a. Sumber daya organisasi berasal dari para penyumbang yang tidak mengharapkan pembayaran kembali atau manfaat ekonomi yang sebanding dengan jumlah sumber daya yang diberikan.

b. Menghasilkan barang dan atau jasa tanpa bertujuan memupuk laba, dan jika organisasi menghasilkan laba, maka jumlahnya tidak untuk dibagikan kepada para pendiri atau pemilik organisasi tersebut. ${ }^{20}$

Sebagaimana halnya pembentukan Otoritas Jasa Keuangan (OJK) dimana dengan tujuan agar keseluruhan kegiatan jasa keuangan di dalam sektor jasa keuangan dapat terselenggara secara teratur, adil, transparan dan akuntabel serta dapat mewujudkan sistem keuangan yang tumbuh secara berkelanjutan dan stabil. ${ }^{21}$ Bidang yang menjadi pengawasan OJK antara lain meliputi industri perbankan, asuransi, dana pensiun, pasar modal, perusahaan pembiayaan, serta badan-badan lain yang menyelenggarakan pengelolaan dana masyarakat. $^{22}$ Otoritas Jasa Keuangan dibentuk dengan tujuan agar keseluruhan kegiatan jasa keuangan di dalam sektor jasa keuangan dapat terselenggara secara teratur, adil, transparan dan akuntabel serta dapat mewujudkan sistem keuangan yang tumbuh secara berkelanjutan dan stabil. Di dalam Undang-Undang Nomor 21 Tahun 2011, Otoritas Jasa Keuangan mempunyai wewenang sebagai berikut:

1. Menetapkan kebijakan operasional pengawasan terhadap kegiatan jasa keuangan.

2. Mengawasi pelaksanaan tugas pengawasan yang dilaksanakan oleh kepala eksekutif.

3. Melaksanakan pengawasan, pemeriksaan penyidikan, perlindungan konsumen, dan tindakan lain terhadap lembaga jasa keuangan.

4. Memberikan perintah tertulis kepada lembaga jasa keuangan dan atau pihak tertentu.

5. Melakukan penunjukan pengelolaan statuter.

6. Menetapkan penggunaan pengelolaan statute.

19 Widodo Hertanto dan Tenten Kustiawan, Akuntansi dan Manajemen Keuangan untuk Organisasi Pengelolaan Zakat, (Bandung: Institusi Manajemen Zakat, 2001), h. 4

${ }^{20}$ Widodo Hertanto dan Tenten Kustiawan, Akuntansi dan Manajemen Keuangan untuk Organisasi Pengelolaan Zakat, h. 4

${ }^{21}$ Tim Panitia Antar Departemen Rancangan Undang-Undang tentang Otoritas Jasa Keuangan, Naskah Akademik Pembentukan Otoritas Jasa Keuangan, h. 3-4.

${ }^{22}$ Lihat Pasal 6 Undang-Undang Nomor 21 Tahun 2011 tentang Otoritas Jasa Keuangan 
7. Menetapkan sanksi administratif terhadap pihak yang melakukan pelanggaran terhadap peraturan perundang-undangan di sektor jasa keuangan.

8. Memberikan dan atau mencabut; izin usaha, izin orang perseorangan, efektifnya pernyataan pendaftaran, surat tanda terdaftar, persetujuan melakukan kegiatan usaha, pengesahan, persetujuan atau penetapan pembubaran dan penetapan lain sebagaimana dimaksud dalam peraturan perundang-undangan di sektor jasa keuangan.

OJK juga memiliki struktur unsur chek and balances. Hal ini diwujudkan dengan melakukan pemisahan yang jelas antara fungsi pengaturan dan fungsi pengawasan. ${ }^{23}$ Fungsi pengaturan dilakukan oleh dewan komisioner yang juga organ tertinggi dalam OJK di mana selain melaksanakan fungsi pengaturan juga berperan untuk memastikan masing-masing pengawas yang melaksanakan tugasnya sesuai dengan peraturan perundang-undangan. Fungsi pengawasan dilakukan masing-masing oleh pengawas bidang jasa keuangan. Adanya pemisahan tersebut diharapakan dapat terciptanya spesialisasi dalam pengawasan, pengembangan metode pengawasan yang tepat serta mengurangi luasnya rentang kendali pengawasan agar proses pengambilan keputusan dan pelaksanaan atas keputusan tersebut menjadi lebih efesien dan efektif. Dengan demikian, pemisahan pengawasan tersebut akan mewujudkan efektivitas pengawasan terhadap kegiatan jasa keuangan untuk masing-masing bidang.

Menurut Sujamto, pengawasan adalah usaha atau kegiatan untuk mengetahui dan menilai kenyataan yang sebenarnya tentang pelaksanaan tugas atau kegiatan, sesuai atau tidak dengan semestinya. ${ }^{24}$ Sementara menurut Sofyan Safri Harahap, pengawasan merupakan suatu usaha agar rencana yang sudah ditetapkan dapat tercapai sebagaimana mestinya. ${ }^{25}$ Dari beberapa pengertian tersebut, pengawasan yang dimaksud adalah pengawasan untuk lebih menjamin bahwa semua kegiatan yang diselenggarakan dalam suatu organisasi didasarkan pada suatu rencana, termasuk suatu strategi yang telah ditetapkan sebelumnya. Pengawasan diperlukan untuk mencegah terjadinya deviasi dalam operasionalisasi suatu rencana, sehingga berbagai kegiatan operasional yang sedang berlangsung terlaksana dengan baik, dalam artian bukan hanya sesuai dengan rencana, melainkan juga dengan efesien dan

\footnotetext{
${ }^{23}$ Tim Panitia antar Depatemen Rancangan Undang-Undang tentang Otoritas Jasa Keuangan, Naskah Akademik Pembentukan Otoritas Jasa Keuangan,(Jakarta: 2010). h. 5.

${ }^{24}$ Sujamto, Aspek-Aspek Pengawasan di Indonesia, (Bandung: Sinar Grafika, 1986), h. 19.

${ }^{25}$ Sofyan Safri Harahap, Akuntansi Pengawasan Manajemen dalam Perspektif Islam (Jakarta: Fakultas Ekonomi Universitas Trisakti, 1992), h. 77.
} 
efektivitas yang setinggi mungkin. Menurut Sujamto, terdapat tiga jenis pengawasan yakni :

a. Pengawasan dilihat dari hubungan antara subyek dan obyek pengawasan:

1) Pengawasan internal, pengawasan yang dilaksanakan dari luar, dalam pengawasan ini subyek pengawas berada di luar susunan obyek yang diawasi.

2) Pengawasan intern, yakni pengawasan dari dalam dimana subyek pengawasan berada dalam struktur organisasi.

b. Dilihat dari pelaksanaan pengawasan, terdiri dari:

1) Pengawasan preventif, yakni pengawasan yang dilakukan sebelum pelaksanaan kerja

2) Pengawasan represif, yakni pengawasan yang dilakukan setelah atau ketika kegiatan dilaksanakan. ${ }^{26}$

c. Dilihat dari subyek pengawasannya terdiri:

1) Pengawasan langsung, yakni pengawasan yang dilakukan dengan cara mendatangi dan melakukan pemeriksaan di tempat terhadap obyek pengawasan.

2) Pengawasan tidak langsung, yakni pengawasan yang dilakukan dengan tidak mendatangi obyek pengawasan.

Dari uraian di atas menunjukkan bahwa tujuan diadakannya pengawasan adalah untuk mengetahui dan menilai kenyataan yang sebenarnya tentang obyek yang diawasi sesuai dengan yang semestinya atau tidak. Dalam sistem pengawasan dibutuhkan pula unsur internal sebagai bentuk pengawasan melekat dan unsur eksternal sebagai pengawas fungsional. Hasil akhir dari sebuah proses pengawasan akan menjadi fungsi kontrol dari pengawasan itu sendiri. Menurut Sujamto, manfaat ketika kontrol berjalan adalah untuk memonitoring sebuah sistem, memberikan penghargaan serta menegaskan berbagai prilaku positif, menjadikan segala sumber daya tetap berjalan sesuai dengan aturannya, memelihara anggaran, mengkoordinasikan standart hukum, aturan serta norma-norma yang sudah ditetapkan. ${ }^{27}$

Sebagaimana dikemukakan di atas, OJK adalah lembaga yang tugasnya melakukan pengaturan dan pengawasan kegiatan jasa keuangan, termasuk di

${ }^{26}$ Sujamto, Op Cit, h. 23-56.

${ }^{27}$ Cahyo Pramono, "Pengawasan" dinduh dari www.waspadaonline.com dan diakses pada 26 Februari 2015 
dalamnya kegiatan jasa perbankan, pembiayaan, serta industri non bank. ${ }^{28} \mathrm{Hal}$ tersebut seperti yang dikemukakan Darmin Nasution selaku gubernur Bank Indonesia bahwa kedudukan OJK yang independen sebagi berikut:

“OJK itu independen walaupun independensinya tidak sampai seperti BI, artinya dalam RUU OJK itu dikatakan, antara lain pemerintah tidak intervensi terhadap OJK. Meski demikian, Presiden dapat mengambil kebijakan mengenai sektor keuangan dan memerintahkan OJK untuk melaksanakan keputusan kebijakan itu, dan harus disampaikan secara tertulis agar memiliki akuntabilitas yang jelas." 29

Berdasarkan Penjelasan Pasal 34 Undang-Undang Nomor 3 Tahun 2004 ditegaskan bahwa OJK bersifat independen dan kedudukannya berada di luar pemerintah dan berkewajiban menyampaikan laporan kepada BPK dan DPR. Namun dalam pelaksanaan tugas dan wewenang, OJK bertanggungjawab kepada Presiden. Menurut Pasal 4 Undang-Undang Nomor 3 Tahun 2004, untuk memperkuat tugas dan fungsinya, OJK wajib berkoordinasi dengan beberapa lembaga negara lain, seperti Bank Indonesia, kementerian keuangan dan lembaga penjamin simpanan, yang kemudian akan bergabung dalam forum stabilitas sistem keuangan. ${ }^{30}$

Otoritas Jasa Keuangan (OJK) dibentuk dengan tujuan agar keseluruhan kegiatan jasa keuangan di dalam sektor jasa keuangan dapat terselenggara secara teratur, adil, transparan dan akuntabel serta dapat mewujudkan sistem keuangan yang tumbuh secara berkelanjutan dan stabil. Untuk menjamin tujuan pembentukan OJK tersebut, maka OJK harus merupakan bagian dari sistem penyelenggara urusan kenegaraan yang terintegrasi secara baik dengan lembaga-lembaga negara dan pemerintahan lainnya. Di samping itu agar OJK dapat melaksanakan fungsinya secara efektif, maka OJK harus memiliki independensi dalam melaksanakan fungsinya agar dapat terlindungi dari berbagai kepentingan. Independensi ini diwujudkan dalam dua hal. Pertama, secara kelembagaan OJK tidak berada di bawah otoritas lain dalam sistem Pemerintahan Negara Republik Indonesia, dan kedua, secara perseorangan yang memimpin OJK harus memiliki kepastian atas jabatannya berupa jangka waktu jabatan yang tidak bisa diganti sejauh melaksanakan tugas dengan benar dan tidak terlibat dalam kriminalitas.

Saat ini yang sedang dilaksanakan pada organisasi zakat adalah pengawasan terhadap kinerja Badan Amil Zakat dilakukan secara internal oleh

${ }^{28}$ Lihat Pasal 2 Undang-Undang Nomor 21 Tahun 2011 tentang Otoritas Jasa Keuangan

${ }^{29}$ Hasil wawancara Media Indonesia dengan Darmin Nasution tanggal 23 Fenruari 2005.

${ }^{30}$ Lihat Pasal 44 Undang-Undang Nomor 21 Tahun 2011 tentang Otoritas Jasa Keuangan 
Komisi Pengawas Badan Amil Zakat di semua tingkatan, dan secara external oleh Pemerintah dan masyarat. ${ }^{31}$ Undang-Undang Nomor 23 Tahun 2011 tentang Pengelolaan Zakat memberikan amanat perlunya melakukan pengawasan. Pengawasan dilakukan oleh dua pihak yaitu pihak pemerintah melalui Menteri Agama dengan melakukan pengawasan terhadap BAZNAS, BAZNAS Provinsi, BAZNAS Kabupaten/ Kota, dan LAZ. Selain pemerintah pihak lain dalam hal ini masyarakat juga berhak melakukan pengawasan pengawasan terhadap BAZNAZ dan LAZ. Dalam Pasal 34 Undang-Undang Nomor 23 Tahun 2011 tentang Pengelolaan Zakat menyebutkan:

(1) Menteri melaksanakan pembinaan dan pengawasan terhadap BAZNAS, BAZNAS Provinsi, BAZNAS Kabupaten/ Kota dan LAZ.

(2) Gubernur dan Bupati/Walikota melaksananakan pembinaan dan pengawasan terhadap BAZNAS Provinsi, BAZNAS Kabupaten/ Kota, dan LAZ sesuai dengan kewenangannya.

Pasal 35 Undang-Undang Nomor 23 Tahun 2011 ditegaskan bahwa:

(1) Masyarakat dapat berperan serta dalam pembinaan dan pengawasan terhadap BAZNAS dan LAZ.

(2) Pengawasan sebagimana dimaksud pada ayat (1) dilakukan dalam bentuk:

a. Akses terhadap informasi tentang pengelolaan zakat yang dilakukan oleh BAZNAS dan LAZ dan,

b. Penyampaian informasi apabila terjadi penyimpangan dalam pengelolaan zakat yang dilakukan oleh BAZNAS dan LAZ.

Konsep Financial Institution secara eksplisit memang tidak disebut di dalam al-Quran, namun jika yang dimaksud lembaga itu memiliki unsur seperti struktur, manajemen, fungsi serta hak kewajiban, maka semua lembaga disebut jelas dengan indikasi penyebutan setiap kata dalam al-Quran yang menyesuaikan dengan seruan yang tertuju pada suatu perintah. ${ }^{32}$ Contoh penyebutan kata kaum, umat (kelompok masyarakat), muluk (pemerintah), balad (negeri), suq (pasar) dan lain sebagainya, mengidentifikasikan bahwa alQuran mengisyaratkan istilah-istilah tersebut memiliki fungsi dan peran tertentu dalam seruan yang dimaksudkan oleh Allah S.W.T. Demikian juga konsep yang merujuk pada ekonomi, seperti zakat, sedekah, ghanimah, bai, dain, maal dan sebagainya, memiliki fungsi yang dilaksanakan oleh peran masingmasing.

${ }^{31}$ Zainuddin Ali, "Manajemen Pengelolaan Zakat, Infaq dan Shodaqah", diunduh dari http://zainuddinali.blogspot.com/2014 0101 archive.html pada hari Sabtu, 22 februari 2015.

32Veithzal Rivai, Islamic Fiancial Management, (Jakarta: Rajawali Pers, 2008), h. 55 
Islam tidak mengatur secara rinci tentang bentuk lembaga pengelolaan keuangan, akan tetapi Islam memberikan pedoman serta garis besar mengenai lembaga pengelolaan seperti halnya konsep accountability dan trust yang terdapat dalam Q.S. al- Ahzab: 72, konsep keadilan yang terdapat dalam Q.S. al-Nisa: 58, sementara untuk menjaga stabilitas sebuah lembaga, Islam mengajarkan amar ma'ruf nahi munkar konsep tindakan tegas yang terdapat dalam Q.S. al- Imran: 104. ${ }^{33}$ Zakat bukanlah sekedar urusan yang bersifat filantropis kedermawanan, namun juga bersifat otoritatif-impulsif. Oleh karenanya pengelolaan zakat oleh lembaga pengelola zakat harus memiliki kekuatan hukum formal.

Secara umum lembaga amil zakat diartikan sebagai institusi pengelolaan zakat yang sepenuhnya dibentuk atas prakarsa masyarakat dan oleh masyarakat yang bergerak di bidang dakwah, pendidikan, sosial dan kemaslahatan umat Islam. ${ }^{34}$ Keberadaan lembaga zakat memang membentuk paradigma baru terhadap pengelolaan zakat yang selama ini dikelola secara konvensional dan apa adanya, akan tetapi keberadaan lembaga amil zakat juga perlu diatur agar tata kelola pelaksanaan zakat dapat terkoordinasi secara terarah dan berjenjang sehingga penghimpunan, pendistribusian serta pendayagunaan zakat dapat dimaksimalkan.

Keikutsertaan pemimpin agama dan peran pemerintah dalam lembaga zakat menjadi instrumen terbaik untuk mencapai tujuan pengorganisasian lembaga zakat sehingga hal ini juga akan mematangkan kepercayaan masyarakat dalam pelaksanaan zakat. Kendati undang-undang tentang zakat telah diterbitkan, masyarakat masih mempersepsikan bahwa zakat merupakan perintah agama bukan menjadi bagian dari perintah negara. Selama ini, praktik pelaksanaan zakat yang dilakukan secara langsung kepada mustahik (konvensional) lebih dominan dan tidak didesain dalam sebuah konsep pemberdayaan umat yang komprehensif. Kendati bukan sebuah kekeliruan, namun akan lebih efektif dan terukur jika penuaian zakat masyarakat didesain dalam sebuah konsep dan mekanisme pengelolaan zakat yang memiliki target konkret bagi peningkatan kesejahteraan masyarakat.

\section{Sistem Hirarki Kelembagaan Badan Pengelola Zakat}

Badan Amil Zakat (BAZ) merupakan lembaga pengelola zakat yang dibentuk oleh pemerintah dengan berbagai tingkatan baik di tingkat nasional

${ }^{33}$ Veithzal Rivai, Islamic Fiancial Management, h. 59

${ }^{34}$ Handa Habidin S, "Pengertian Lembaga Amil Zakat" diunduh dari, http://penelitianhukum.org/2012/10/30/I-lembaga-amil-zakat-1-2/ pada Hari Selasa, 10 Maret 2015. 
maupun di tingkat daerah bersifat yang koordinatif, konsultatif, dan infimatif. Kepengurusan BAZ terdiri dari unsur masyarakat dan pemerintah yang memenuhi persyaratan tertentu seperti sifat amanah, adil berdedikasi, profesional dan berintegrasi tinggi. Berbeda dengan BAZ, Lembaga Amil Zakat (LAZ) merupakan bentukan masyarakat yang dikukuhkan, dibina, dan dilindungi oleh pemerintah. Pengukuhan LAZ sesuai dengan Keputusan Menteri Agama Nomor 373 Tahun 2003 tentang Pelaksanaan Undang-Undang Nomor 38 Tahun 1999 tentang Pengelolaan Zakat. LAZ dapat dikukuhkan atas permohonan LAZ setelah memenuhi persyaratan sebagai berikut: ${ }^{35}$

1) Berbadan hukum

2) Memiliki data muzakki dan mustahik

3) Telah beroprasi minimal 2 tahun

4) Memiliki laporan keuangan yang telah diaudit oleh akuntan publik selama 2 tahun terakhir

5) Memiliki wilayah operasi (untuk tingkat nasional 10 provinsi, untuk tingkat provinsi $40 \%$ kabupaten atau kota

6) Mendapat rekomendasi dari Forum Zakat

7) Telah mampu mengumpulkan dana 1 milyar dalam setahun untuk sekala nasional atau lima ratus ajuta untuk tingkat provinsi.

8) Melampirkan surat pernyataan bersedia disuvei oleh tim dan akuntan publik

9) Dalam melaksanakan kegiatan bersedia berkoordiansi dengan BAZ dan Departemen Agama setempat.

Sistem pengadministrasian lembaga zakat juga harus didasarkan pada prinsip yang sehat, agar lembaga zakat dapat berkembang dengan baik. Adapun beberapa prinsip tersebut antara lain: ${ }^{36}$

1.Penangung jawab tertinggi sejatinya adalah pemerintah atau pejabat tertinggi dalam strata pemerintahan dengan mengikutsertakan tokoh-tokoh Islam;

2.Pelaksana pengelola zakat adalah lembaga tetap dengan pegawai yang bekerja penuh secara profesional;

3.Kebijakan harus dirumuskan secara jelas dan dipergunakan sebagai dasar perencanaan, penghimpunan dan pendayagunaan zakat;

4.Pendayagunaan zakat harus terinci agar efektif dan produktif untuk pengembangan ekonomi masyarakat;

\footnotetext{
${ }^{35}$ Ahmad Supardi Hasibuan, "Kebijaksanaan Pemerintah tentang Pengelolaan Zakat", Makalah Tahun 2012

${ }^{36}$ Yuke Rahmawati, Lembaga Keuangan Mikro Syariah, (Jakarta: UIN Jakarta Press, 2013), h. 62
} 


\section{Mufidah}

5.Mekanisme pengawasan diperlukan untuk ketertiban pengadministrasian dan pembukuan layaknya perusahaan keuangan yang mempunyai kredibilitas pengelolaan serta pengendali oraganisasi;

6.Auditor juga termasuk dalam komponen kebutuhan lembaga zakat dikarenakan organisasi zakat penghimpun dana dalam jumlah besar dan untuk menjamin pelaksanaan zakat sebagai amanah agama dan kewajiban warganegara Islam terhadap Peraturan Perundangundangan tentang zakat;

7.Penyuluhan yakni untuk menciptakan kondisi yang kondusif dalam menarik partisipasi masyarakat untuk menunaikan ibadah zakat secara teratur dan berkelanjutan.

Dalam BAB II Pasal 5 ayat (3) Undang-Undang Nomor 23 Tahun 2011 tentang Pengelolaan Zakat ditegaskan bahwa; BAZNAZ sebagaimana dimaksud pada ayat (1) merupakan lembaga pemerintah non struktural yang bersifat mandiri dan bertanggungjawab kepada Presiden melalui Menteri.

Merujuk pada ketentuan di atas, terdapat ketidaksiapan pemerintah untuk mengintegrasikan peraturan serta sistem birokrasi antar lembaga atau badan yang seharusnya bersinergi dengan BAZNAS. Pemerintah hanya melegalkan zakat tanpa membuat standar prosedur sehingga zakat serta badan pengelolanya yakni BAZNAS beroperasi secara terpisah dengan lembaga lainnya. Sistem pertanggungjawabannya pun terlihat amat sederhana tanpa adanya auditor. Sebuah lembaga yang mengelola dana dengan nilai milyaran atau bahkan dalam jumlah trilyunan dengan skala nasinal ini merupakan celah terjadinya ketidaksesuaian. Dengan demikian, kekurangan peraturan perundang-undangan tersebut dirasa semakin lengkap selain semua peran yang dirangkap BAZ (regulator, motivator, fasilitator dan koordinator) sebagai representasi peran pemerintah. Pada konteks ini, muncul sebuah pertanyaan siapakah yang berhak mengaudit lembaga LAZ, dan siapa yang berhak mengaudit BAZ.

Dapat ditegaskan bahwa zakat bukanlah sekedar urusan yang bersifat filantropis kedermawanan, namun juga bersifat otoritatif-impulsif oleh karenanya pengelolaan zakat oleh lembaga pengelola zakat harus memiliki kekuatan hukum formal. Fungsi hukum formal tersebut tentu bukan hanya sebagai payung hukum melainkan juga sebagai kontribusi sebuah peraturan penertiban dan sistem tata kelola pelaksanaan zakat.

Merujuk pada sebuah teori sistem, seharusnya sistem berkaitan erat dengan berdirinya suatu negara dimana sistem membantu untuk 
mempermudah mencapai sebuah tujuan tertentu. Istilah sistem paling sering digunakan untuk menunjuk pengertian metode atau cara dan sesuatu himpunan unsur atau komponen yang saling berhubungan satu sama lain menjadi satu kesatuan yang utuh. Menurut Dewey Decimal Classification, istilah sistem digunakan untuk menunjuk pengertian skema atau metode pengaturan organisasi atau susunan sesuatu, atau tata cara, jelasnya yaitu suatu bentuk atau pola pengaturan, pelaksanaan, atau pemrosesan. ${ }^{37}$ Sistem juga disusun untuk menjamin adanya perlakuan yang seragam terhadap transaksi yang terjadi dalam suatu organisasi yang dimaksud tersebut. ${ }^{38}$ Jika hukum diartikan sebagai sebuah sistem, maka hukum merupakan suatu kesatuan, yang unsur-unsur, sub-sub sistem atau elemen-elemennya saling berkaitan, saling pengaruh dan mempengaruhi serta saling memperkuat atau memperlemah antara yang satu dan yang lainnya karena tidak dapat dipisahkan. ${ }^{39}$

Di Indonesia, realitas produk perundang-undangan masuk dalam paradigma simbiotik (symbiotic paradigm) yakni konsep yang memandang agama dan negara berhubungan secara simbiotik. Hubungan timbal balik dan saling memerlukan. Agama memerlukan negara agar agama dapat berkembang dan sebaliknya negara memerlukan agama agar negara dapat berkembang dalam bimbingan etika dan moral. ${ }^{40}$ Hubungan timbal balik ini dirasa sangat identik dengan budaya masyarakat Indonesia yang sangat kental dengan nuansa Islam, hal ini karena penduduk Indonesia mayoritas adalah muslim.

Di dalam ilmu hukum melihat obyek hukum sebagai suatu structured whole adalah bentuk sebuah sistem, disebabkan adanya keterkaitan yang sistematis antara berbagai peraturan yang ada. Hukum sebagai suatu sistem memiliki makna peraturan yang terdiri dari bagian-bagian atau unsur-unsur yang saling berkaitan satu dengan yang lain seperti peraturan hukum, asas hukum serta pengertian hukum. Manajemen pengelolaan zakat merupakan bentuk dari structured whole yang seharusnya teraplikasi secara otomatis karena zakat bukan lagi bagian dari perintah agama semata, akan tetapi dengan formalisasi zakat melalui undang-undang maka zakat juga merupakan kehendak pemerintah. Pemberlakuan hukum tersebut tercermin sebagai sebuah

\footnotetext{
37Tatang M. Amirin, Pokok-Pokok Teori Sistem, (Jakarta: PT. Raja Grafindo Persada, 2003), h. 3.

${ }^{38}$ Baridwan Zaki, Sistem Akuntansi; Penyusunan Prosedur dan Metode, (Yogyakarta: BP FE Universitas Gajah Mada, 1991), h.3.

${ }^{39}$ Ilham Bisri, Sistem Hukum Indonesia; Prinsip-prinsip dan Implementasi Hukum di Indonesia, (Jakarta: PT. Raja Grafindo Persada, 2005), h. 6.

${ }^{40} \mathrm{Abu}$ Zahra, Politik Demi Tuhan: Nasionalisme Religius di Indonesia, (Bandung: Pustaka Hidayah, 1999), h. 45-51.
} 
sistem, di mana sistem hukum merupakan seperangkat operasional yang meliputi institusi, prosedur atau aturan, dan bukan sekedar payung hukum. ${ }^{41}$

Tujuan disahkannya zakat dalam bentuk undang-undang sudah hampir dipastikan untuk membangun sebuah sistem yang mana tujuan dari pada pengaturan zakat adalah dalam rangka meningkatkan kesadaran masyarakat dalam penuaian dan dalam pelayanan ibadah zakat. Selain itu juga merupakan upaya untuk meningkatkan fungsi dan peranan pranata keagamaan dalam upaya mewujudkan kesejahteraan masyarakat dan keadilan sosial serta meningkatkan hasil guna dan daya guna zakat secara maksimal. ${ }^{42}$

Bentuk dari struktur whole dari lahirnya Undang-Undang Nomor 23 Tahun 2011 tentang Pengelolaan Zakat adalah bahwa undang-undang tersebut telah menjadi bagian dari sistem hukum yang terbangun dalam sistem tata negara Indonesia, hanya saja memang undang-undang ini berdiri sendiri dan tidak bersinergi dengan lembaga keuangan yang ada di Indonesia. Seharusnya karena zakat merupakan perintah agama, maka sinergi dapat dilakukan dengan lembaga pemerintah lainnya yang memang membidangi hal yang sama yakni agama. Demikian halnya penyesuaian yang seharusnya di bangun dalam hal sinergitas sebagai lembaga pengelola keuangan. Sebagaimana dalam setiap bidang lembaga keuangan tentu memerlukan badan independen sebagai pengawas dan pendukung lembaga tersebut agar tugas, fungsi dan wewenang sebuah lembaga keuangan tersebut konsisten sesuai tujuannya.

Usaha pemerintah membentuk OJK sebagaimana amanat dari UndangUndang Nomor 21 Tahun 2011 memiliki fungsi sebagai penyelenggara sistem pengaturan dan pengawasan yang terintegrasi terhadap keseluruhan kegiatan di dalam sektor jasa keuangan, baik di sektor perbankan maupun non-bank, lembaga pembiayaan, reksadana serta lembaga jasa keuangan lainnya. ${ }^{43} \mathrm{Hal}$ tersebut merupakan bentuk keseriusan pemerintah dalam membangun sistem agar terlaksana tata kelola yang baik dalam lembaga pengelola keuangan.

Pengelolaan zakat dalam bentuk managemen satu bentuk dari berbagai macam jenis jasa pengelolaan keuangan yang ada di Indonesia. Dalam setiap bidang lembaga keuangan tentu memerlukan badan independen sebagai pengawas dan pendukung lembaga agar tugas, fungsi dan wewenang sebuah lembaga keuangan tersebut konsisten sesuai dengan tujuannya. Hal ini tidak

\footnotetext{
${ }^{41}$ Muhammad Ali, Pengaruh Pasal 1 Ayat (3) UUD 1945 Terhadap Penguatan Negara Hukum Indonesia, (Bandung: Ringkasan Disertasi, 2012), h. 20.

${ }^{42}$ Gustian Djuanda dkk, Pengelolaan Zakat PengurangPajakPenghasilan, (Jakarta: PT. Raja GrafindoPersada, 2006), h. 4.

${ }^{43}$ Lihat Pasal 4 Undang-Undang Nomor 21 Tahun 2011 tentang Otoritas Jasa Keuangan
} 
dapat diterapkan pada sistem pengelolaan zakat karena lemahnya sinergi dan belum adanya keseriusan pemerintah untuk membangun sistem terkait pelaksanaan dan pengelolaan zakat.

Tujuan diadakannya pengawasan adalah untuk mengetahui dan menilai kenyataan yang sebenarnya tentang obyek yang diawasi sesuai dengan yang semestinya atau tidak. Dalam sistem pengawasan dibutuhkan pula unsur internal sebagai bentuk pengawasan melekat dan unsur eksternal sebagai pengawas fungsional. Hasil akhir dari sebuah proses pengawasan akan menjadi fungsi kontrol dari pengawasan itu sendiri. Manfaat ketika kontrol berjalan adalah untuk memonitoring sebuah sistem, memberikan penghargaan serta menegaskan berbagai prilaku positif, menjadikan segala sumber daya tetap berjalan sesuai dengan aturannya, memelihara anggaran, mengkoordinasikan standar hukum, aturan serta norma-norma yang sudah ditetapkan.

Pemberian kewenangan yang berlebihan tanpa ada kontrol tentu akan menciptakan peluang terjadinya penyalahgunaan. Formalisasi zakat melalui peraturan perundang-undangan maka dibutuhkan pula ketegasan pemerintah dengan seperangkat prosedur dan pedoman serta aturan sebagai konsekuensi sebuah sistem yang lahir dari undang-undang tersebut bukan sekedar legalitas semata. Pengawasan yang dimaksud adalah untuk lebih menjamin bahwa semua kegiatan yang diselenggarakan dalam suatu organisasi didasarkan pada suatu rencana, termasuk suatu strategi yang telah ditetapkan sebelumnya. Pengawasan diperlukan untuk mencegah terjadinya deviasi dalam operasionalisasi suatu rencana, sehingga berbagai kegiatan operasional yang sedang berlangsung terlaksana dengan baik, dalam artian bukan hanya sesuai dengan rencana, melainkan juga dengan efesien dan efektivitas yang setinggi mungkin.

\section{Pustaka Acuan}

Ali, Muhammad, Pengaruh Pasal 1 Ayat (3) UUD 1945 Terhadap Penguatan Negara Hukum Indonesia, Bandung: Ringkasan Disertasi, 2012.

Amirin, Tatang M, Pokok-Pokok Teori Sistem, Jakarta: PT. Raja Grafindo Persada, 2003.

Bisri, Ilham, Sistem Hukum Indonesia; Prinsip-prinsip dan Implementasi Hukum di Indonesia, Jakarta: PT. Raja Grafindo Persada, 2005

Direktorat Jenderal Bimbingan Masyarakat Islam dan Penyelenggaran Haji Depag RI, Manajemen Pengelolaan Zakat, (Jakarta: Dirjen Bimas Islam dan Penyelenggaran Haji Depag RI 2004) 


\section{Mufidah}

Djuanda, Gustian dkk, Pengelolaan Zakat Pengurang Pajak Penghasilan, Jakarta: PT. Raja Grafindo Persada, 2006.

Djuanda, Gustian dkk, Pengelolaan Zakat PengurangPajakPenghasilan, (Jakarta: PT. Raja GrafindoPersada, 2006.

Fakhruddin, Figh dan Manajemen Zakat di Indonesia, Malang: UIN-Malang Press, 2008.

Hertanto, Widodo dan Tenten Kustiawan, Akuntansi dan Manajemen Keuangan untuk Organisasi Pengelolaan Zakat, Bandung: Institusi Manajemen Zakat, 2001.

Kementrian Agama RI, Standarisasi Amil Zakat di Indonesia (Jakarta: Direktorat Jenderal Bimbingan Masyarakat Islam, Direktorat Pemberdayaan Zakat, 2013.

Muhammad Syah, Ismail dkk, Filsafat Hukum Islam, (PT BumiAksara, Jakarta, 1999, Cet. III.

Rahmawati, Yuke, Lembaga Keuangan Mikro Syariah, (Jakarta: UIN Jakarta Press, 2013.

Rivai, Veithzal, Islamic Fiancial Management, Jakarta: Rajawali Pers, 2008.

Salim, Arskal, Pengelolaan Zakat dalam Politik Orde Baru dalam Problematika Zakat Kontemporer; Artikulasi Proses Sosial Politik Budaya, Jakarta: Forum Zakat (FOZ), 2003.

Safri Harahap, Sofyan, Akuntansi Pengawasan Manajemen dalam Perspektif Islam, Jakarta: Fakultas Ekonomi Universitas Trisakti, 1992.

Shihab, Quraish, Membumikan Al Quran, Bandung: Mizan, 1999), Cet. XIX

Suradi dan Mujiyadi, Pemberdayaan Masyarakat Miskin (Studi Evaluasi Penanggulangan Kemiskinan di Lima Provinsi, Jakarta: P3KS Press, 2009.

Sujamto, Aspek-Aspek Pengawasan di Indonesia, Bandung: Sinar Grafika, 1986.

Tim Panitia antar Depatemen Rancangan Undang-Undang tentang Otoritas Jasa Keuangan, Naskah Akademik Pembentukan Otoritas Jasa Keuangan, Jakarta: 2010.

Tulus, Pemberdayaan Lembaga Pengelolaan Zakat dan Kaitannya dengan Pajak, Jakarta: Forum Zakat, 2003.

Zaki, Baridwan, Sistem Akuntansi; Penyusunan Prosedur dan Metode, Yogyakarta: BP FE - Universitas Gajah Mada, 1991.

Zahra, Abu, Politik Demi Tuhan: Nasionalisme Religius di Indonesia, Bandung: Pustaka Hidayah, 1999.

\section{Undang-Undang}

Undang-Undang Dasar Negara Republik Indonesia 1945

Undang-Undang Nomor 14 Tahun 1967 tentang Pokok-Pokok Perbankan 
Surat Keputusan Menteri Nomor 792 Tahun 1990

Undang-Undang Nomor 21 Tahun 2011 tentang Otoritas Jasa Keuangan

\section{Artikel}

Abdullah Kelib, "Falsafah Zakat dalam Hukum Islam" artikel dalam Majalah Hukum, Vol I Tahun 2007.

Ahmad Supardi Hasibuan, "Kebijaksanaan Pemerintah tentang Pengelolaan Zakat", Makalah Tahun 2012

\section{Internet}

"Kelemahan Undang-Undang Zakat" lihat http://bwi.or.id/index.php/ar/beritamainmenu-109/313-uu-zakat-miliki-tiga-kelemahan, (Rabu, 17 September 2014). "Tikungan Tajam Amil Zakat" diunduh dari www. kliping.kemenag.go.id/download.php\% (Senin 14 April 2014), h.102-103.

Cahyo Pramono, "Pengawasan" dinduh dari www.waspadaonline.com dan diakses pada 26 Februari 201

Zainuddin Ali, "Manajemen Pengelolaan Zakat, Infaq dan Shodaqah", diunduh dari http://zainuddinaliblogspot.com/20140101 archive.html pada hari Sabtu, 22 februari 2015.

Handa Habidin S, "Pengertian Lembaga Amil Zakat" diunduh dari, http://penelitianhukum.org/2012/10/30/I-lembaga-amil-zakat-1-2/ pada Hari Selasa, 10 Maret 2015. 
Mufidah

344 - Jurnal Cita Hukum. Vol. 4 No. 2 Desember 2016. P-ISSN: 2356-1440. E-ISSN: 2502-230X 